\title{
In Vivo Stimulation of the Insulin Receptor Kinase in Human Skeletal Muscle Correlation with Insulin-stimulated Glucose Disposal during Euglycemic Clamp Studies
}

\author{
Gary R. Freidenberg, " Stephan L. Suter," Robert R. Henry, Donna Reichart," and Jerrold M. Olefsky" \\ From the Departments of *Pediatrics and ${ }^{\$}$ Medicine, University of California, San Diego, La Jolla, California 92093; the "San Diego \\ Veterans Administration Medical Center, San Diego, California 92161; and ${ }^{\ddagger}$ University Hospital, 8091 Zurich, Switzerland
}

\begin{abstract}
To assess the relationship between insulin receptor (IR) kinase activity and insulin action in vivo in humans, we measured glucose disposal rates (GDR) during a series of euglycemic clamp studies. Simultaneously, we measured IR kinase activity in IRs extracted from skeletal muscle obtained by needle biopsy at the end of each clamp. By preserving the phosphorylation state of the receptors as it existed in vivo at the time of biopsy, we could correlate GDR and IR kinase in skeletal muscle. Eight nondiabetic, nonobese male subjects underwent studies at insulin infusion rates of $0,40,120$, and $1,200 \mathrm{mU} / \mathrm{m}^{2}$ per min. Kinase activity, determined with receptors immobilized on insulin agarose beads, was measured at $0.5 \mu M$ ATP, with $1 \mathrm{mg} / \mathrm{ml}$ histone, followed by SDS-PAGE. Insulin increased GDR approximately sevenfold with a half-maximal effect at $\sim 100 \mu \mathrm{U} / \mathrm{ml}$ insulin and a maximal effect by $\sim \mathbf{4 0 0} \mu \mathrm{U} / \mathrm{ml}$. Insulin also increased IR kinase activity; the half-maximal effect occurred at $\sim 500-600 \mu \mathrm{U} / \mathrm{ml}$ insulin with a maximal 10-fold stimulation over basal. Within the physiologic range of insulin concentrations, GDR increased linearly with kinase activation $(P$ $<0.0006$ ); at supraphysiologic insulin levels, this relationship became curvilinear. Half-maximal and maximal insulin-stimulated GDR occurred at $\sim 20$ and $\sim 50 \%$ maximal kinase activation, respectively. These results are consistent with a role of the kinase in insulin action in vivo. Furthermore, they demonstrate the presence of a large amount of "spare kinase" for glucose disposal. (J. Clin. Invest. 1991. 87:2222-2229.) Key words: skeletal muscle $\bullet$ insulin receptor kinase • glucase disposal
\end{abstract}

\section{Introduction}

Many studies now strongly indicate that the insulin receptor (IR) ${ }^{1}$ tyrosine kinase is critical for insulin action. For example, studies in which site-directed mutagenesis of the IR cDNA was used to make a kinase-defective IR, showed that the mutant receptor failed to mediate insulin action after its transfection into cultured cells (1-3). In other studies, naturally occurring mutations and deletions were detected within the kinase domain of the insulin receptors from three unrelated patients with severe forms of insulin resistance (4-6). Finally, it has

Address reprint requests to Gary R. Freidenberg, M.D., UCSD School of Medicine, M-009-C, La Jolla, CA 92093.

Received for publication 20 August 1990 and in revised form 8 January 1991.

1. Abbreviations used in this paper: GDR, glucose disposal rate; IR, insulin receptor.

The Journal of Clinical Investigation, Inc.

Volume 87, June 1991, 2222-2229 been shown that intracellular injection of anti-insulin receptor antibodies, which inhibited IR kinase activity, also effectively blocked insulin action in Xenopus oocytes (7).

Although these studies indicate that the kinase activity of the receptor is critical for insulin's bioeffects, this prerequisite has not been established in vivo nor has a clear relationship between kinase activity and insulin stimulation of glucose disposal been demonstrated in humans. In fact, the results of studies designed to assess this relationship have been quite disparate. On one hand, Takayama et al. found a positive relationship between kinase activity and in vitro glucose transport in freshly isolated human adipocytes (8). Thies and colleagues recently reported similar results in human adipocytes using Western blotting to measure IR kinase activity (9). In contrast to these two studies, our previous studies did not show a correlation between maximal in vivo insulin-stimulated glucose disposal and in vitro insulin-stimulated kinase activity measured using adipocyte-derived insulin receptors from either obese or diabetic humans (10). The relationship between kinase activity and in vivo insulin action is further confounded by preliminary results of other investigators who reported a negative correlation between insulin-stimulated kinase activity and insulinmediated glucose disposal measured in control and diabetic humans (11).

Given these various results, it is not yet apparent if the IR kinase is related to insulin action in vivo. To assess this relationship in detail, we have measured insulin-mediated glucose disposal during a series of euglycemic insulin clamps. Simultaneously, we quantitated insulin-stimulated kinase activity in insulin receptors isolated from biopsies of skeletal muscle taken at the end of each clamp study. By use of a technique which preserves receptor kinase activity as it existed in vivo at the time of biopsy, we could directly determine the ability of insulin to activate the kinase under physiologic conditions and compare the results with activation of glucose disposal in vivo.

\section{Methods}

Materials. Monocomponent porcine insulin and $\left[{ }^{125} \mathrm{I}-\mathrm{Tyr} \mathrm{A}^{14}\right]$ monoiodoinsulin and [ ${ }^{125}$ I]IGF-1 were generous gifts from Dr. Bruce Frank and $R$. Chance (Lilly, Indianapolis, IN). [ $\left.\gamma-{ }^{32} \mathrm{P}\right] \mathrm{ATP}(6,000 \mathrm{Ci} / \mathrm{mmol})$ was purchased from New England Nuclear, Boston, MA. BSA fraction V, was obtained from Armour Pharmaceutical Co., Chicago, IL, CNBr-activated Sepharose from Pharmacia Fine Chemicals, Piscataway, NJ, wheat germ agarose beads from Vector Laboratories, Inc., Burlingame, CA, histone 2B from Worthington Co., Freehold, NJ, and aprotinin from Farbenfabriken Beyer Ag Pharmaceuticals, New York, NY. The following reagents were purchased from Sigma Chemical Co., St. Louis, MO: cytosine triphosphate (CTP), phenylmethylsulfonyl fluoride (PMSF), and Triton X-100. All materials for protein determination and SDS-PAGE were from Bio-Rad Laboratories, Richmond, CA. 3- $\left[{ }^{3} \mathrm{H}\right]$ glucose was obtained New England Nuclear.

Patients. The study population consisted of eight paid volunteers. None of the subjects took any medication known to alter glucose toler- 
ance. Volunteers were admitted to the Veterans Administration Medical Center, and informed consent was obtained. The subjects were fed a solid isocaloric diet followed by an overnight fast and a standard 75-g 3-h oral glucose tolerance test. Based on criteria established by the National Diabetes Data Group (12), none of the subjects was diabetic. Based upon relative body mass indices (BMI), none of the patients was considered obese. The characteristics of the subjects are displayed in Table I.

Euglycemic clamp studies. In vivo insulin sensitivity was assessed by a modification of the euglycemic glucose-clamp technique as previously described (13). After a 12-h overnight fast, an intravenous catheter was inserted into an antecubital vein for infusion of insulin, glucose, and potassium phosphate. Another catheter, placed retrograde into a dorsal hand vein, which was kept in a warming device at $70^{\circ} \mathrm{C}$, was used for blood sampling. A series of four euglycemic clamp studies were done in each subject; two studies were done on one day and two more on another day at least $24 \mathrm{~h}$ later. For each of the four clamps, plasma glucose measurements were done at 5 -min intervals and adjustments were made, as necessary, in the rate of infusion of a $20 \%$ dextrose solution, to maintain the plasma glucose at $90 \mathrm{mg} / \mathrm{dl}$. During the final $40 \mathrm{~min}$ of each study period, glucose disposal rates (GDR) were measured as the average of four measurements taken every $10 \mathrm{~min}$. A biopsy was then taken of the vastus lateralis, using the technique of Bergstrom (14); the muscle was immediately frozen in liquid nitrogen for use in subsequent kinase assays. Muscle biopsies were done at comparable anatomical positions on alternating legs at the end of successive studies.

On the first study day, a constant infusion of $\left[{ }^{3} \mathrm{H}\right]$ glucose was administered for quantitation of endogenous glucose production. After 3 $\mathrm{h}$ of infusion, basal Rd was measured and a muscle biopsy taken. The three clamps were then done on the second and third study days. For these, a primed continuous infusion of insulin was given at 40,120 , or $1,200 \mathrm{mU} / \mathrm{m}^{2}$ per min; GDR was measured after $4 \mathrm{~h}$ for the 40 - and $120-\mathrm{mU}$ clamps, and after $2 \mathrm{~h}$ for the 1,200-mU clamp. A muscle biopsy was taken at the end of each clamp. The 40- and 120-mU clamps were done randomly on separate days. The $1,200-\mathrm{mU}$ clamp directly followed the $120-\mathrm{mU}$ clamp on the same day. This use of sequential clamps may overestimate GDR in the $1,200 \mathrm{mU}$ clamp relative to the $120-\mathrm{mU}$ clamp due to the longer time of total insulin infusion in the $1,200-\mathrm{mU}$ clamp. However, we have previously noted that with a 4-h infusion for the $120-\mathrm{mU}$ clamp, this overestimation is $<10 \%$ (15). An overestimation of this magnitude would produce little change in apparent insulin sensitivity of GDR.

Calculations. GDR was calculated by the isotope dilution method for the basal study using the Steele equations (16) in their modified

Table I. Characteristics of Eight Nondiabetic, Nonobese Subjects

\begin{tabular}{ccccc}
\hline Patient & Age & Weight & FFM $^{*}$ & BMI \\
\hline & $y r$ & $k g$ & $k g$ & $\mathrm{~kg} / \mathrm{m}^{2}$ \\
1 & 39 & 80.5 & 69.7 & 23.5 \\
2 & 30 & 70.0 & 53.1 & 22.9 \\
3 & 33 & 70.5 & 60.8 & 24.7 \\
4 & 35 & 73.2 & 63.5 & 24.7 \\
5 & 45 & 63.6 & 48.9 & 24.2 \\
6 & 39 & 64.9 & 54.9 & 22.4 \\
7 & 38 & 72.1 & - & 25.2 \\
8 & 27 & 81.4 & 57.4 & 23.7 \\
Mean & 35.7 & 71.2 & 57.4 & 23.7 \\
& $5.3^{\ddagger}$ & $2.5^{5}$ & $2.7^{5}$ & $0.5^{5}$
\end{tabular}

* Fat-free mass, calculated from underwater weighing. ${ }^{\star}$ Standard deviation. ${ }^{5} \mathrm{SEM}$. derivative form (17). For the other three clamps, GDR was calculated as the rate of infusion of exogenous glucose at steady state; in doing so, we have assumed complete suppression of hepatic glucose production at the levels of insulinemia achieved during these clamps. This assumption has been previously validated in nondiabetic, nonobese subjects (18).

Analytical methods. Insulin was assayed by a double-antibody radioimmunoassay according to the method of Desbuquois and Aurbach (19). Glucose levels were measured by the glucose oxidase method using a glucose analyzer (Yellow Springs Instrument Co., Yellow Springs, $\mathrm{OH}$ ).

Preparation of insulin receptors from skeletal muscle. Skeletal muscle was homogenized and solubilized on ice for $30 \mathrm{~min}$ in solubilizing buffer (60 mg wet weight muscle $/ \mathrm{ml}$ ) containing $2.0 \%$ Triton X-100, 4 $\mathrm{mM}$ orthovanadate, $10 \mathrm{mg} / \mathrm{ml}$ bacitracin, $4.5 \mathrm{mM}$ PMSF, $10 \mathrm{mM}$ benzamidine, $300 \mathrm{KIU} / \mathrm{ml}$ aprotinin, $20 \mathrm{mM}$ EDTA, $20 \mathrm{mM}$ sodium pyrophosphate, $150 \mathrm{mM} \mathrm{NaF}, 2 \mathrm{mM}$ dichloroacetic acid, and $50 \mathrm{mM}$ Hepes, pH 7.4. After centrifugation at $100,000 \mathrm{~g}$ for $15 \mathrm{~min}$, the soluble extract was diluted fivefold with buffer A ( $120 \mathrm{mM} \mathrm{NaCl}, 1 \mathrm{mM} \mathrm{KCl}, 1$ $\mathrm{mM} \mathrm{CaCl}_{2}, 1 \mathrm{mM} \mathrm{MgSO}_{4}, 2 \mathrm{mM}$ orthovanadate, $50 \mathrm{mM} \mathrm{NaF}, 10 \mathrm{mM}$ pyrophosphate, $5 \mathrm{mM}$ EDTA, $300 \mathrm{KIU} / \mathrm{ml}$ aprotinin, $2 \mathrm{mM}$ PMSF, $10 \%$ glycerol, $0.05 \%$ Triton, and $25 \mathrm{mM}$ Hepes, $\mathrm{pH}$ 7.4) and cycled twice over a $0.75-\mathrm{ml}$ wheat germ agglutinin column, a procedure by which $>95 \%$ of muscle-derived insulin receptors adsorbed to the lectin column. After washing the column in buffer A, the receptors were eluted with buffer A supplemented with $0.3 \mathrm{M} \mathrm{N}$-acetyl-glucosamine and four to five fractions ( $200 \mu \mathrm{l}$ each) containing $\sim 80 \%$ of the insulin binding activity were pooled, aliquoted, and frozen at $-70^{\circ} \mathrm{C}$ for use in measuring insulin binding and receptor kinase activity.

Insulin binding studies. Insulin binding studies were done on receptors prepared from each of four biopsies from each subject. To measure binding, aliquots of the frozen receptor preparations were first diluted $1: 1$ and incubated in triplicate with $\left.{ }^{[25} \mathrm{I}-\mathrm{Tyr} \mathrm{A}^{14}\right]$ insulin (final concentration $1 \mathrm{ng} / \mathrm{ml}$ ) at $4^{\circ} \mathrm{C}$ for $18 \mathrm{~h}$ in the absence and presence of varying concentrations of unlabeled insulin in a total volume of $40 \mu$ l. The amount of receptor-bound hormone was determined by the polyethylene glycol precipitation method as previously described (20).

Preparation of insulin affinity agarose. Insulin Sepharose was prepared using $\mathrm{CnBr}$-activated Sepharose and a modification of the method of Cuatrecasas (21) as described by Olson et al. (22). The dried derivatized agarose was linked to porcine insulin $(4 \mathrm{mg} / \mathrm{ml})$ in $100 \mathrm{mM}$ sodium phosphate buffer, pH 6.4, containing $6 \mathrm{M}$ urea. After $1 \mathrm{~h}$, the beads were separated by gravity, and $40 \mathrm{ml}$ of a $1-\mathrm{M}$ glycine solution was added for $3 \mathrm{~h}$.

Immobilization of insulin receptors on insulin affinity Sepharose. For the measurement of insulin receptor kinase activity, insulin Sepharose beads were washed extensively using a modification of the procedure of Olson et al. (22). Briefly, an aliquot of insulin Sepharose beads were washed with 50 column volumes of $0.5 \%(\mathrm{wt} / \mathrm{vol}) \mathrm{SDS}$ in water followed by 50 column volumes of a solution containing $6 \mathrm{M}$ urea, $2 \mathrm{M}$ $\mathrm{NaCl}, 50 \mathrm{mM}$ Tris, $100 \mathrm{mM} \mathrm{Na}_{2} \mathrm{HPO}_{4}, \mathrm{pH} 7.4$, followed by 50 column volumes of $2 \%$ SDS and finally by 50 column volumes of $50 \mathrm{mM}$ Hepes ( $\mathrm{pH}$ 7.4). The washed beads were pelleted by centrifugation and resuspended 1:1 (vol/vol) in $50 \mathrm{mM}$ Hepes. Aliquots of the resuspended beads $(50 \mu \mathrm{l})$ were incubated for $1 \mathrm{~h}$ at $24^{\circ} \mathrm{C}$ with $1 \mathrm{ml}$ of buffer B (0.05\% Triton X-100, $100 \mathrm{mM} \mathrm{NaCl}, 2.5 \mathrm{mM} \mathrm{KCl}, 1 \mathrm{mM} \mathrm{CaCl}_{2}, 1$ $\mathrm{mM} \mathrm{MgSO}_{4}, 25 \mathrm{mM}$ Hepes, $10 \%$ (wt/vol) glycerol, $2 \mathrm{mM}$ sodium orthovanadate, $10 \mathrm{mM}$ sodium pyrophosphate, and $100 \mathrm{mM} \mathrm{NaF}, \mathrm{pH}$ 7.4) supplemented with $5 \%$ nonfat dried milk. The beads were then separated by centrifugation, the buffer discarded, and aliquots $(40 \mathrm{fmol}$ of insulin binding capacity) of the preactivated, wheat germ-purified receptor preparations were added at $4^{\circ} \mathrm{C}$ along with $200 \mu l$ buffer $B$ made with $10 \%$ nonfat dried milk, pH 7.4. The tubes were rotated end over end for $16 \mathrm{~h}$ at $4^{\circ} \mathrm{C}$, after which the beads were separated by centrifugation and washed four times at $4^{\circ} \mathrm{C}$ with $1 \mathrm{ml}$ of buffer $\mathrm{C}$ (buffer $\mathrm{B}$ minus the $\mathrm{NaF}$ and pyrophosphate) and finally resuspended in $40 \mu$ l of buffer $\mathrm{C}(\mathrm{pH} \mathrm{7.6)}$ for kinase assays. As reported by Olson et al. (22), our control studies indicated that $\sim 90 \%$ of the available insu- 
lin receptor kinase activity bound to the insulin affinity beads under the assay conditions.

Insulin receptor kinase reactions. Phosphorylation assays were performed in duplicate with insulin receptors immobilized on insulin-Sepharose beads. The phosphorylation reactions were initiated by the addition of a reaction mixture calculated to give final concentrations of $5 \mathrm{mM} \mathrm{MnCl}{ }_{2}, 10 \mathrm{mM} \mathrm{MgCl} 2,500 \mu \mathrm{M} \mathrm{CTP}, 0.5 \mu \mathrm{M}$ [ $\gamma$-32P]ATP ( 160 $\mu \mathrm{Ci} / \mathrm{nmol}$ ) in the presence of $1 \mathrm{mg} / \mathrm{ml}$ histone $2 \mathrm{~B}$. After incubation at $4^{\circ} \mathrm{C}$ for $20 \mathrm{~min}$, the reactions were terminated by the addition of Laemmli's reducing buffer and the supernatants analyzed on $12 \%$ polyacrylamide gels. For quantitation, areas of the dried gels corresponding to insulin-stimulated ${ }^{32} \mathrm{P}$-labeled proteins, were excised and counted in a scintillation counter. Equal areas of gel judged free of radioactivity were counted as background. Although all kinase studies were done using $\mathbf{4 0} \mathrm{fmol}$ of receptors, the kinase reaction performed as outlined, was linear up to at least $200 \mathrm{fmol}$ given the volume of insulin-affinity beads used.

Data analysis. All values are given as mean \pm SEM unless otherwise indicated. Statistical comparisons were done using analysis of variance. Pairwise comparisons were done using paired $t$ tests with the Bonferroni correction.

\section{Results}

Insulin clamp studies. GDRs were determined at the end of four euglycemic clamp studies done on each subject. The steady-state levels of plasma glucose and serum insulin attained at the end of the four study periods are shown in Table II. These results confirm that all four clamps were performed at a similar level of euglycemia. The glucose disposal rates achieved at the various levels of insulinemia are graphed in Fig. 1. Insulin increased GDR by 5-11-fold in all subjects, with a mean fold increase of $6.97 \pm 0.73$. The half-maximal effect $o c$ curred at $\sim 100 \mu \mathrm{U} / \mathrm{ml}$ which is slightly below the mean insulin level observed during the $40 \mathrm{mU}$ clamp (Table II). GDR was nearly maximal $(91.6 \pm 3.5 \%)$ at a mean insulin level of 381 $\mu \mathrm{U} / \mathrm{ml}$ reached during the $120-\mathrm{mU}$ clamp and further increases in serum insulin, up to a mean pharmacologic level of $16,973 \mu \mathrm{U} / \mathrm{ml}$ attained during the $1,200 \mathrm{mU}$ clamp, increased GDR minimally.

Insulin binding. Insulin binding capacity of the partially purified lectin preparations are shown in Fig. $2 \mathrm{~A}$. As shown, total insulin binding capacity obtained from muscles biopsied in the basal state was equivalent to that measured from the three insulin infusion clamps. These results suggest that within the length of time over which insulin was infused, no loss of total cellular insulin receptors occurred, which is consistent with the findings in rat adipocytes where a loss of total cellular insulin receptors occurred only after $12 \mathrm{~h}$ or more exposure to

Table II. Steady-state Levels of Plasma Glucose and Serum Insulin at the End of Four Euglycemic Clamps

\begin{tabular}{lcccc}
\hline & \multicolumn{4}{c}{ Insulin infusion rate $\left(\mathrm{mU} / \mathrm{m}^{2}\right.$ per min $)$} \\
\cline { 2 - 5 } & 0 & 40 & 120 & 1200 \\
\hline $\begin{array}{c}\text { Plasma glucose } \\
(m g / d l)\end{array}$ & $92.9 \pm 2.4$ & $88.3 \pm 0.9$ & $87.7 \pm 1.2$ & $92.2 \pm 1.3$ \\
$\begin{array}{c}\text { Serum insulin } \\
(\mu U / m l)^{*}\end{array}$ & $8.7 \pm 1.6$ & $119.9 \pm 16.3$ & $381.0 \pm 38.6$ & $16973 \pm 971$
\end{tabular}

* Mean \pm SEM.

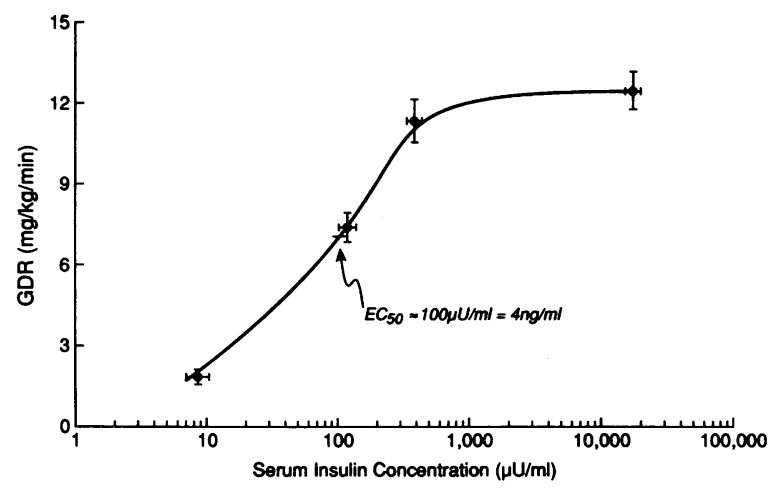

Figure 1. Dose-response stimulation of in vivo glucose disposal by insulin. Glucose disposal was measured at euglycemia in eight nondiabetic, nonobese males in the absence of exogenous insulin (basal value) and at the end of three primed continuous infusions of insulin delivered at steady-state rates of 40,120 , and $1,200 \mathrm{mU} / \mathrm{m}^{2}$ per min. The results are displayed as the mean \pm SEM of serum insulin levels and GDR.

insulin (23). The amount of muscle obtained per biopsy was $251 \pm 52 \mathrm{mg}$ in the basal state, $282 \pm 64 \mathrm{mg}$ in the $40 \mathrm{mU}$ clamp, $231 \pm 39 \mathrm{mg}$ in the $120-\mathrm{mU}$ clamp, and $218 \pm 29 \mathrm{mg}$ in the 1,200-mU clamp. Overall, the approximate yield of receptors recovered per milligram of muscle was $3 \mathrm{fmol}$ per wet weight mg of muscle and this was similar in all the clamps. The affinity of insulin for its receptor, as judged by the amount of unlabeled insulin which displaced half of the tracer insulin, is shown in Fig. $2 B$ where the binding data have been formated as a percent of tracer binding. Half-maximal displacement of labeled insulin was not statistically different among the groups.

Skeletal muscle contains insulin and IGF-1 receptors (2426). Insulin has been shown to bind to the IGF-1 receptor, albeit with less affinity compared with IGF-1 $(24,26)$. Thus, the presence of IGF-1 receptors in the lectin preparations could spuriously increase insulin binding measurements. To assess this possibility, we measured IGF-1 binding and determined the ability of unlabeled insulin to displace labeled IGF-1. Plotted as a percent of tracer binding, the results in Fig. 3 show the relative potency of IGF- 1 and insulin for the IGF-1 receptor. Half-maximal displacement of labeled IGF-1 by unlabeled IGF-1 occurred at $\sim 15 \mathrm{ng} / \mathrm{ml}$. In contrast, unlabeled insulin, even at concentrations up to $10,000 \mathrm{ng} / \mathrm{ml}$ did not appear to displace any labeled IGF-1. Thus, our receptor preparations contained IGF-1 receptors, but these receptors bound little, if any, insulin. The estimated number of IGF-1 receptors was approximately twofold greater than the number of insulin receptors (data not shown). Competition studies were also done with labeled insulin. As seen in Fig. 3, half-maximal displacement of labeled insulin occurred at $12 \mathrm{ng} / \mathrm{ml}$ unlabeled insulin but at $6,500 \mathrm{ng} / \mathrm{ml}$ unlabeled IGF-1. Thus, IGF-1 was able to bind to insulin receptors but with $\sim 500$-fold less potency compared with insulin.

In related studies, in five of the eight subjects, we also measured insulin binding at $50 \mathrm{ng} / \mathrm{ml}$ in the presence of $25 \mathrm{ng} / \mathrm{ml}$ unlabeled IGF-1, a concentration which produces $\sim 40 \%$ IGF1 receptor occupancy but no occupancy of the insulin receptor. The results of these experiments showed that in the presence of IGF-1, insulin binding was unchanged (data not shown). With 

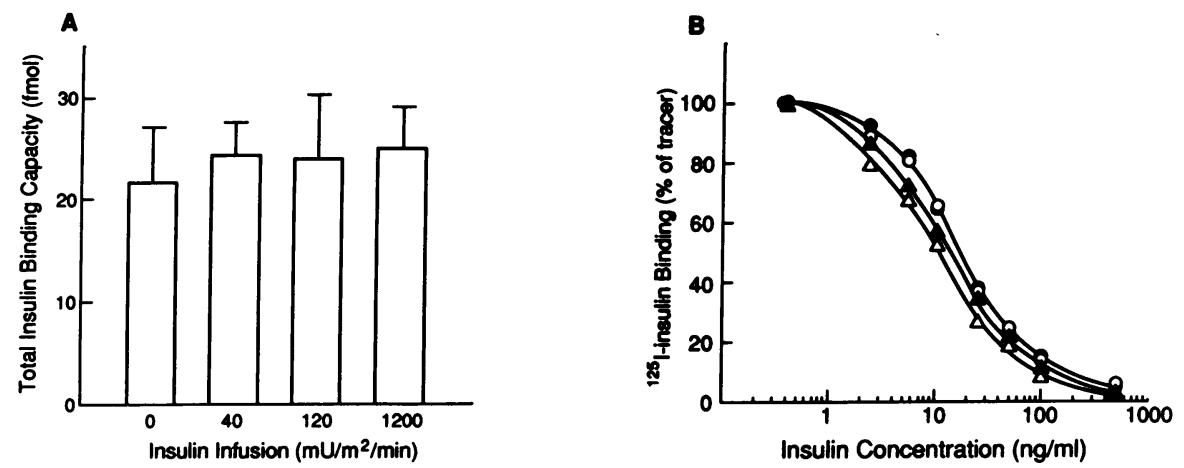

Figure 2. Insulin binding during euglycemic clamps. Insulin binding was measured using insulin receptor preparations made from the muscle biopsies taken at the end of each of the four euglycemic clamps done in the eight subjects. Binding studies were conducted after partial purification of the receptors over wheat germ agglutinin, as described in the Methods. $(A)$ Normalized for the amount of eluted glycoprotein, the number of receptors was calculated from the estimated $x$-intercept of the Scatchard plots drawn for each receptor preparation and are shown as the mean \pm SEM of the collective results from each of the four clamp studies. $(B)$ Insulin competition studies were done as described in Methods. The results are displayed as a percent of tracer binding for the basal (•), 40-mU (0), 120-mU ( $\triangle)$, and 1,200-mU ( $\Delta$ ) clamps.

the results in Fig. 3, these data are consistent with the conclusion that insulin did not bind to IGF-1 receptors in our system.

Activation of insulin receptor kinase in vivo. Insulin receptors, whose kinase activity was preactivated at the various insulin levels achieved during the three clamp studies, were immobilized on insulin agarose and exposed to histone and $\left[\gamma-{ }^{32} \mathrm{P}\right]-$ ATP. Results from a single subject are seen in Fig. 4. Two insulin-stimulated bands are visible. The upper phosphoprotein corresponds to the $\beta$-subunit of the insulin receptor, and the lower phosphoprotein represents histone. The bands corresponding to these two phosphoproteins were excised and counted to measure in vivo insulin stimulation of the insulin receptor kinase. In general, the values for kinase activity, determined by quantitation of $\beta$-subunit or histone phosphorylation were comparable. In fact, analysis of this relationship revealed a highly significant $(r=0.897, n=32, P<0.0001)$ correlation (data not shown). Thus, under the current assay conditions, using preactivated receptors, phosphorylation of the $\beta$-subunit of the insulin receptor appeared to reflect the same information as did phosphorylation of the exogenous substrate, histone. As we have noted previously, the concentration of ATP used in these assays $(0.5 \mu \mathrm{M})$ precluded activation of previously unac-

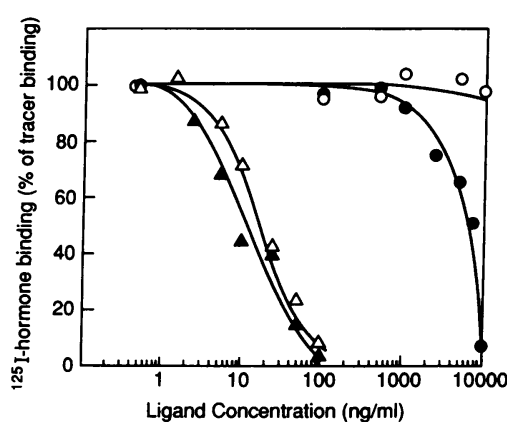

Figure 3. Insulin and IGF-1 binding in receptor preparations. Aliquots of receptors were incubated with either labeled IGF-1 $(0.5 \mathrm{ng} /$ $\mathrm{ml}$, final concentration) or labeled insulin $(0.5$ $\mathrm{ng} / \mathrm{ml}$, final concentration) in the presence of increasing amounts of the unlabeled homologous or heterologous ligand. At the end of 16

$\mathrm{h}$ at $4^{\circ} \mathrm{C}$, polyethylene glycol was used to separate bound and free hormone. The results, expressed as a percent of tracer binding, show competition by unlabeled IGF-1 $(\Delta, \bullet)$ or unlabeled insulin $(\Delta, 0)$ for labeled IGF-1 $(0, \Delta)$ or labeled insulin $(\Delta, \bullet)$. Nonspecific binding was measured in the presence of $5,000 \mathrm{ng} / \mathrm{ml}$ insulin $(\Delta, \bullet)$ or 5,000 $\mathrm{ng} / \mathrm{ml} \mathrm{IGF-1}(\Delta, 0)$. The results are displayed as the mean of two experiments. tivated receptors, even in the presence of insulin, and also prevented further activation of already active receptors (27). Thus, the type of "autophosphorylation" observed in these studies did not produce any change in kinase activation and, phosphorylation of the $\beta$-subunit could, therefore, be interpreted like phosphorylation of an exogenous substrate.

Insulin dose response curves. Insulin dose response curves for kinase activation are graphed in Fig. 5 for all eight subjects. Insulin increased the mean incorporation of ${ }^{32} \mathrm{P}$ into the $\beta$-subunit by $9.67 \pm 2.86$-fold (Fig. $5 \mathrm{~A}$ ) and into histone by a mean of $10.0 \pm 2.25$-fold (Fig. $5 \mathrm{~B}$ ). The half-maximal effect of insulin occurred at $600 \mu \mathrm{U} / \mathrm{ml}$ for both $\beta$-subunit and histone phosphorylation. Mean basal kinase, measured in the absence of infused insulin, accounted for $13.4 \pm 2.6 \%$ (Fig. $5 \mathrm{~A}$ ) of maximally insulin-stimulated kinase activity when ascertained by quantitation of the $\beta$-subunit. The mean kinase activity increased to $21.8 \pm 4.0 \%(P<0.0175$ compared to basal $)$ and $44.8 \pm 7.3 \%(P<0.0034$ relative to basal) of maximum during the 40 - and $120-\mathrm{mU}$ clamps, respectively. Similar insulin-me-

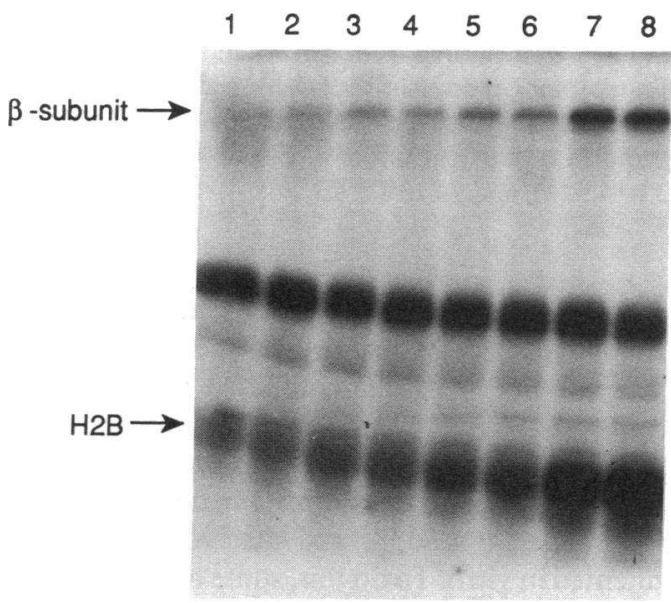

Figure 4. Insulin-stimulated kinase activation in vivo in a single subject. Insulin receptors, prepared from each of the four clamp studies in one subject, were used to measure insulin receptor tyrosine kinase activity using the techniques described in Methods. Shown here is the autoradiogram of the results for the $\beta$-subunit and histone. The results are shown in duplicate for the basal (lanes 1,2), 40-mU (lanes 3,4 ), 120-mU (lanes 5, 6), and 1,200-mU (lanes 7, 8) clamps. 
A

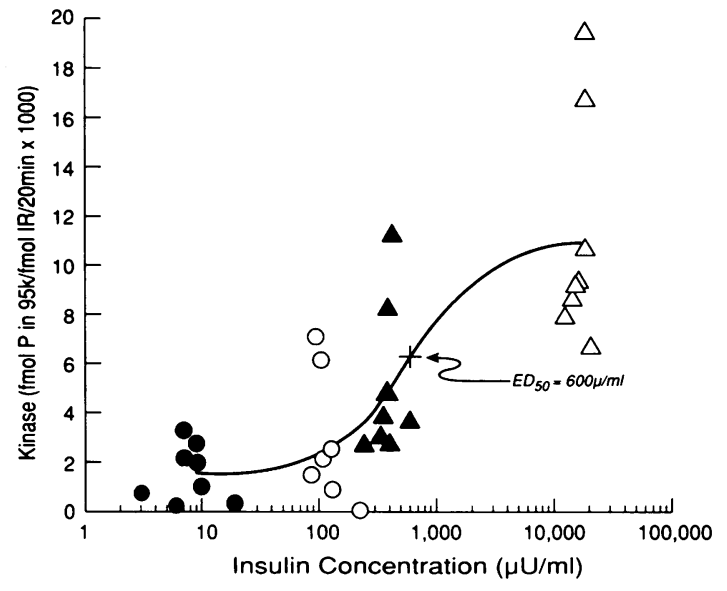

B

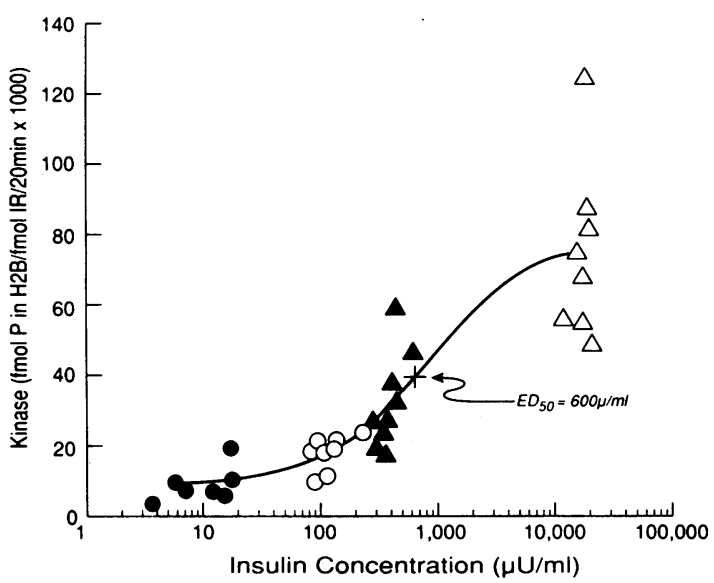

Figure 5. Insulin-stimulated activation of insulin receptor kinase activity. Tyrosine kinase activity was measured using insulin receptors purified from muscle biopsies taken at the end of the four euglycemic clamp studies described in Fig. 1. The results are normalized for $\mathbf{4 0}$ fmol of insulin binding activity and are plotted as the individual data

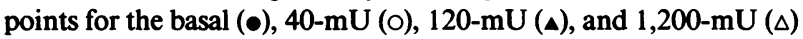
clamps for kinase activity, measured using quantitation of the $\beta$-subunit of the insulin receptor $(A)$ and histone $(B)$ for eight control subjects. The mean \pm SEM kinase values in $A$ were $1.6 \pm 0.4(\bullet), 2.7 \pm 0.8$ $(0), 4.8 \pm 1.1(\Delta)$, and $11.0 \pm 1.6(\Delta)$; values in $B$ were $10.2 \pm 2.0(\bullet)$, $18.1 \pm 1.8(0), 33.0 \pm 4.9(\Delta)$, and $74.1 \pm 8.5(\Delta)$.

diated increases were noted when histone phosphorylation was quantitated (Fig. $5 \mathrm{~B}$ ). Mean histone kinase activity was $14.8 \pm 3.3 \%, 25.5 \pm 3.2 \%(P<0.0003$ compared to basal $)$, and $44.3 \pm 4.2 \%$ ( $P<0.0001$ compared to basal) of maximum at basal and during the 40 - and $120-\mathrm{mU}$ clamps, respectively.

In all studies, we sought to determine whether the kinase activity of the Sepharose-bound, preactivated receptors could be further augmented in vitro. To do this, some of the immobilized receptors were exposed to a large concentration of unlabeled ATP which was then removed by extensive washing before subsequent kinase measurements. The results of these experiments are shown in Fig. 6. ATP increased histone phosphorylation by twofold over that measured in receptors from the 1,200-mU clamp studies and nearly completely blocked phosphorylation of the $\beta$-subunit. ATP treatment of receptors from the basal, $40-\mathrm{mU}$, and $120-\mathrm{mU}$ clamps pro-

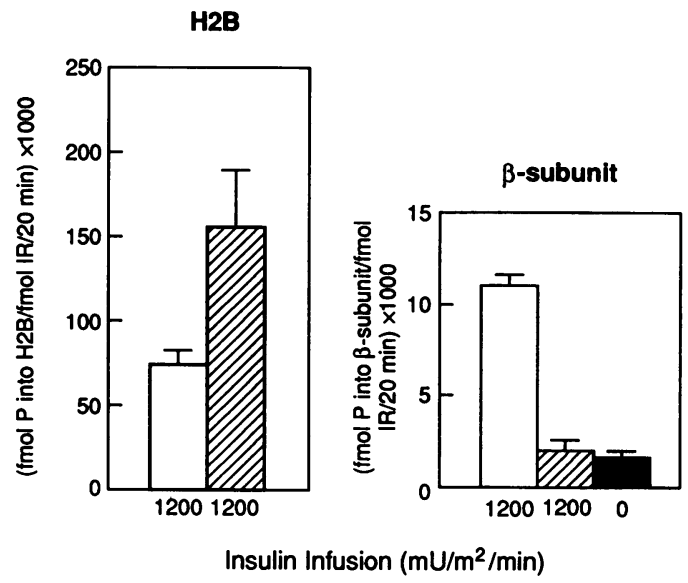

Figure 6. Augmentation of kinase activity by ATP in vitro. Some of the receptors $(40 \mathrm{fmol})$ from the 1,200 -mU clamps were immobilized on insulin-affinity beads and exposed to $500 \mu \mathrm{M}$ unlabeled ATP and $5 \mathrm{mM} \mathrm{MnCl}{ }_{2}$ for $1 \mathrm{~h}$, followed by extensive washing with buffer $\mathrm{C}$ to remove the excess ATP, before performing the kinase assay at 0.5 $\mu \mathrm{M}$ ATP. The results represent the amount of phosphorylation (mean \pm SEM) of histone and the $\beta$-subunit with (hatched bars) and without (open bars) augmentation by ATP in vitro for all eight subjects. For comparison, basal $\beta$-subunit phosphorylation, in the absence of extra ATP, is shown (solid bar).

duced the same magnitude of histone phosphorylation as did receptors from the 1,200-mU clamp (data not shown).

Correlation of serum insulin levels and kinase activation. When graphed on semilog plots, as shown in Fig. 5, the kinase data appeared to reveal a sigmoidal relationship when examined as a function of serum insulin levels. However, when the same data were plotted on a linear scale, a simpler curvilinear relationship was suggested. For example, using the data from Fig. $5 B$ for histone phosphorylation, the points corresponding to the values from the basal, $40-\mathrm{mU}$, and $120-\mathrm{mU}$ clamps, had a highly significant linear relationship with serum insulin levels ( $r=0.828, n=24, P<0.0001)$ as demonstrated in Fig. 7; a similar relationship ( $r=0.66, n=24, P<0.005$ ) existed for $\beta$-subunit phosphorylation (data not shown). This relationship seemed to depart from linearity at insulin concentrations equal to or greater than those encountered during the $120-\mathrm{mU}$ clamp

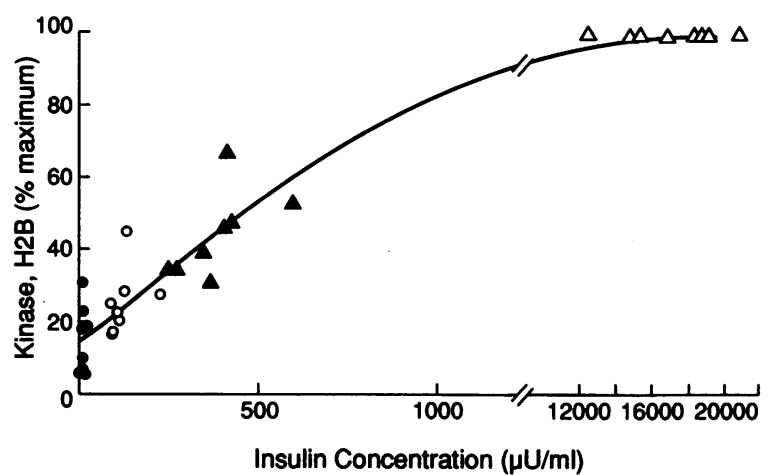

Figure 7. Linearity of the insulin dose response for activation of insulin receptor kinase activity. The individual data from Fig. $6 \mathrm{~B}$ are shown using a nonlogarithmic coordinate system. The values correspond to the kinase activity from the basal $(\bullet), 40-\mathrm{mU}(0), 120-\mathrm{mU}$ $(\triangle)$, and 1,200-mU $(\Delta)$ clamps. 

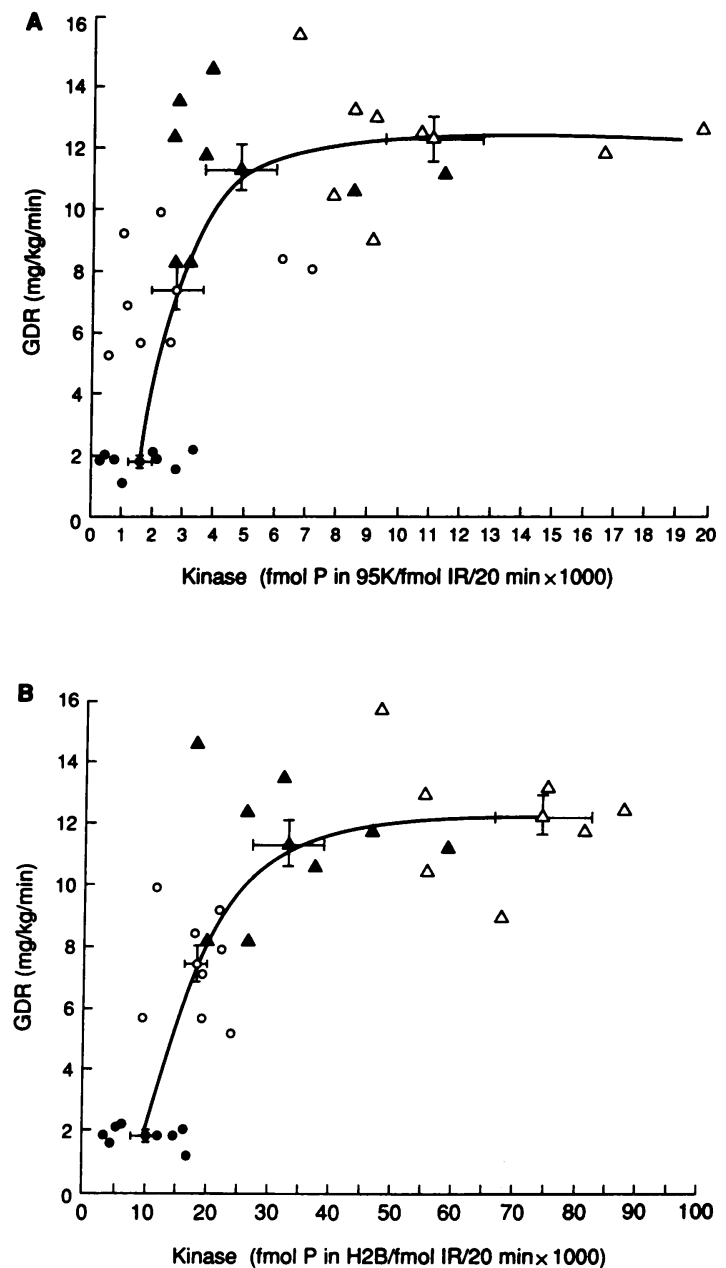

Figure 8. Correlation of in vivo insulin receptor kinase activity and in vivo glucose disposal. The individual kinase results are graphed against the corresponding values of GDR measured at the end of the

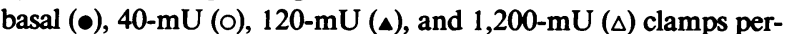
formed on the eight subjects. Shown are the mean \pm SEM of GDR and kinase activity, measured in terms of $\beta$-subunit phosphorylation $(A)$ and histone phosphorylation $(B)$.

so that, for a given increment in serum insulin, kinase activation increased at a much slower rate for insulin values within the pharmacologic range.

Correlation of kinase activity and GDR. Clearly, insulin increased both GDR and kinase activation in vivo. However, the rates of activation were not the same for the two processes as shown by the curvilinear relationship between kinase activity and GDR as illustrated in Fig. 8. This nonlinear relationship showed that glucose disposal was half-maximally stimulated when the insulin receptor kinase activity was between $18 \%$ (Fig. $8 \mathrm{~A}$ ) and $24 \%$ (Fig. $8 \mathrm{~B}$ ) maximally stimulated. Thus, substantial activation of glucose disposal by insulin occurred at relatively low levels of kinase activity. Also apparent from Fig. 8 is that nearly maximal glucose disposal occurred at levels of kinase activation which were only approximately half-maximal.

Although the correlation between insulin-mediated kinase activation and insulin-stimulated glucose disposal was curvilinear, as demonstrated in Fig. 8, the initial part of the curve appeared quite linear. In fact, linear regression of the data points, including all but those of the $1,200 \mathrm{mU}$ clamp, revealed a significant correspondence for both $\beta$-subunit ( $r=0.473, n$ $=24, P<0.02)$ and histone $(r=0.647, n=24, P<0.0006)$ phosphorylation.

Whereas the relative increases in receptor kinase activity and GDR were strongly correlated, the absolute increases in these two parameters were not. In the case of histone phosphorylation, this was true for all incremental changes including the interval between the basal study and the 40-mU clamp ( $r$ $=0.10)$, the basal and the 120-mU clamp $(r=-0.16)$, and the $40-$ and $120-\mathrm{mU}$ clamps $(r=-0.03)$. A similar lack of correlation was noted when the data were analyzed using $\beta$-subunit phosphorylation instead of histone phosphorylation.

\section{Discussion}

The results of our studies show for the first time that insulin, infused in vivo, increases the activation of the tyrosine kinase activity of insulin receptors extracted from human skeletal muscle. This effect was dose-dependent and quantitatively comparable when assessed with phosphorylation of either the $\beta$-subunit of the receptor or with the exogenous substrate, histone. The half-maximal effect occurred at 500-600 $\mu \mathrm{U} / \mathrm{ml}$ $(20-24 \mathrm{ng} / \mathrm{ml})$ insulin. This is close to the value of $12-15 \mathrm{ng} / \mathrm{ml}$ insulin which we and others have reported for half-maximal activation of the insulin receptor kinase activity of intact human and rat adipocytes exposed to insulin in vitro $(9,27)$.

As expected, insulin also increased glucose disposal in a dose-dependent manner. Glucose disposal was half-maximal at $\sim 100 \mu \mathrm{U} / \mathrm{ml}$ insulin and clearly maximal at insulin levels around $400-500 \mathrm{mU} / \mathrm{ml}$. These results are in good agreement with earlier in vivo studies $(28,29)$ and confirm the observation that $\sim 90 \%$ of insulin-stimulated GDR occurs within the physiologic range of insulin levels where $<30 \%$ of the total insulin receptors are occupied by insulin. This finding is consistent with the concept of "spare receptors," that is, receptors whose occupation by insulin is not required for a maximal receptor-mediated response, such as glucose disposal, to occur.

Given that the kinase measurements were made using receptors from skeletal muscle, the predominant tissue involved in insulin-mediated glucose disposal (30), we could directly compare the ability of insulin to activate both its receptor kinase as well as glucose disposal. This relationship was curvilinear with half-maximal activation of glucose disposal at $\sim 20 \%$ maximal activation of insulin receptor kinase activity. Glucose disposal was close to maximally activated at $\sim 50 \%$ maximally activated kinase activity. Similar observations have been noted in vitro in intact human adipocytes where maximal stimulation of glucose transport occurred at concentrations of insulin that produced $\sim 40 \%$ maximal activation of kinase activity (9). These observations demonstrate the presence of "spare kinase" for glucose disposal.

The current studies are the first in humans to demonstrate a correlation between insulin receptor kinase activity and any biologic action of insulin measured in vivo in humans. In a previous study, we tried to correlate in vivo insulin-stimulated glucose disposal, measured during a 1,200-mU clamp, and in vitro insulin-stimulated kinase activity, using adipocyte-derived human insulin receptors; however, we did not find any correlation (10). The results of the present studies provide a logical explanation for this earlier lack of correlation. Thus, we now find a highly significant linear relationship between kinase 
activity and GDR, but only for levels of kinase activity less than those associated with maximal glucose disposal. At insulin levels beyond those required for maximal glucose disposal, receptor kinase activity could be further stimulated; in fact, the kinase was twofold higher at insulin concentrations achieved during the $1,200-\mathrm{mU}$ clamps than it was at insulin levels required for maximal glucose disposal. It is the presence of this "spare kinase," that is, kinase whose complete activation is not required for maximal GDR, that probably explains the lack of correlation between maximal kinase activity and maximal GDR in the earlier studies in adipocytes and in the current studies in muscle.

Results similar to ours have been reported in rats subjected to a series of euglycemic clamps. In these studies, insulin-stimulable kinase activity was measured using insulin receptors isolated from rectus abdominis muscle taken at the end of each clamp (31). Collectively, submaximal kinase activity correlated linearly with both rates of glucose disposal and serum insulin concentrations. Whether these linear correlations extended to maximal kinase activity cannot be determined from the data reported. Although these types of results in humans and animals show a strong correlation between stimulation of the receptor kinase and activation of glucose disposal by insulin, they do not prove that kinase activation is a prerequisite for insulinstimulated glucose disposal in vivo. However, when taken together with the results of other studies, showing that kinase-defective insulin receptors failed to mediate insulin action after their transfection into cultured cells (1-3), these observations strongly suggest that kinase activation plays a critical role in in vivo glucose disposal. In a manner analogous to the "spare receptor" concept, the presence of maximal GDR at only a fraction of maximal receptor kinase activity, suggests that changes in kinase activity could alter the sensitivity of glucose disposal to insulin $(32,33)$. In contrast, regulation of the responsiveness of glucose disposal to insulin probably involves factors other than just activation of receptor kinase. In this regard, we found a correlation between the magnitude of stimulation of the kinase by insulin and the amount of glucose disposal (Fig. 8 ), but found no correlation between the insulin-induced increments in kinase activity and GDR across any insulin concentrations.

In our studies, kinase activity increased linearly as a function of serum insulin concentration, but only for values close to the physiologic range. The relationship between insulin levels and kinase activity became curvilinear as insulin levels moved from the physiologic to pharmacologic range as illustrated in Fig. 7. Although the reason for this curvilinearity is not clear, we and others have observed a similar effect when insulin stimulation of the insulin receptor kinase was measured in cell-free systems using solubilized receptors $(20,34,35)$. In these in vitro studies, the increase in kinase activity was linear only up to insulin levels required for occupancy of $\sim 30 \%$ of all insulin receptors. Although not measured in this study, $30 \%$ receptor occupancy occurs, at least in human adipocytes (9), at an insulin level of $12-15 \mathrm{ng} / \mathrm{ml}(300-375 \mu \mathrm{U} / \mathrm{ml})$, which is close to the mean insulin level achieved during the $120-\mathrm{mU}$ clamp.

The binding data suggest that skeletal muscle contains approximately twofold more IGF-1 vs. insulin receptors. The IGF-1 receptor is structurally similar to the insulin receptor and both have tyrosine kinase activity $(36,37)$. Because insulin has been reported to bind to IGF-1 receptors $(24,26)$, it is conceivable that some of the kinase measured in these studies could be the result of insulin cross-binding to the IGF-1 receptor. Given the low affinity with which insulin binds to the IGF1 receptor, activation of the IGF-1 receptor kinase by insulin should only be problematic at the insulin levels achieved during the 1,200-mU clamp. However, the binding studies in Fig. 3 indicate that even this scenario is likely to be minimal because insulin did not bind to the IGF-1 receptor in our lectin preparations.

Exposure of preactivated receptors to large concentrations of ATP in vitro before the kinase assays, resulted in a doubling of the measured maximal histone phosphorylation. Presumably this phenomenon is related to receptor phosphorylation because pretreatment with ATP blocked subsequent incorporation of ${ }^{32} \mathrm{P}$ into the $\beta$-subunit. Previously, we observed a qualitatively similar result in rat adipocytes exposed to insulin in vitro (27). The cause of the augmentation of histone kinase activity in preactivated receptors is unclear. Likely, it relates to the phosphorylation of intracellular receptors never exposed to insulin in vivo, or to rephosphorylation of receptors which were dephosphorylated during their intracellular transit. We cannot exclude the possibility that some receptors, deactivated during cell solubilization and subsequent receptor preparation, were also rephosphorylated in vitro.

Our current studies indicate that insulin receptor kinase activity can readily be measured using small amounts of skeletal muscle obtained by needle biopsy. Sequential biopsies, taken from the same subject, are possible and practical. This type of approach is particularly meaningful because the kinase measurements can be made using techniques such that the kinase activity measured in vitro reflects the kinase activity of the insulin receptors at the time of the muscle biopsy. Kinase activity, measured in this way reflects the complex physiological interaction of the insulin receptor tyrosine kinase with cellular phosphatases, ATPases, and other kinases; this type of complexity is not taken into account when kinase activation by insulin is done in vitro.

\section{Acknowledgments}

The authors thank the nurses of the Special Diagnositic and Treatment Unit of the San Diego Veterans Administration Medical Center.

This work was supported in part by grants from the National Institutes of Health (DK 33651) and the Veterans Administration Research Service.

\section{References}

1. Chou, C. K., T. J. Dull, D. S. Russell, R. Gherzi, D. Lebwohl, A. Ullich, and O. M. Rosen. 1987. Human insulin receptors mutated at the ATP-binding site lack protein tyrosine kinase activity and fail to mediate postreceptor effects of insulin. $J$. Biol Chem 262:1842-1847.

2. McClain, D. A., H. Maegawa, J. Lee, T. J. Dull, A. Ullrich, and J. M. Olefsky. 1987. A mutant insulin receptor with defective tyrosine kinase displays not biologic activity and does not undergo endocytosis. J. Biol. Chem. 262:14663-14671.

3. Ebina, Y., E. Araki, M. Taira, F. Shimada, M. Mori, C. S. Craik, K. Siddle, S. B. Pierce, R. A. Roth, and W. J. Rutter. 1987. Replacement of lysine residue 1030 in the putative ATP-binding region of the insulin receptor abolishes insulin and antibody-stimulated glucose uptake and receptor kinase activity. Proc. Natl. Acad. Sci. USA. 84:704-708.

4. Moller, D. E., and J. S. Flier. 1988. Detection of an alteration in the insulin receptor gene in a patient with insulin resistance, acanthosis nigricans, and the polycystic ovary syndrome (type A insulin resistance). N. Engl. J. Med. 319:1526-1529.

5. Odawara, M., T. Kadowaki, R. Yamamoto, Y. Shibasaki, K. Tobe, D. Accili, C. Bevins, Y. Mikami, N. Matsuura, Y. Akanuma, F. Takaku, S. I. Taylor, 
and M. Kasuga. 1989. Human diabetes associated with a mutation in the tyrosine kinase domain of the insulin receptor. Science (Wash. DC). 245:66-68.

6. Taira, M., N. Hashimoto, F. Shimada, Y. Suzuki, A. Kanatsuka, F. Nakamura, Y. Ebina, M. Tatibana, H. Makino, and S. Yoshida. 1989. Human diabetes associated with a deletion of the tyrosine kinase domain of the insulin receptor. Science (Wash. DC). 245:63-66.

7. Morgan, D. O., L. Ho, L. J. Korn, and R. A. Roth. 1986. Insulin action is blocked by a monoclonal antibody that inhibits the insulin receptor kinase. Proc. Natl. Acad. Sci. USA. 83:328-332.

8. Takayama, S., C. R. Kahn, K. Kubo, and J. E. Foley. 1988. Alterations in insulin receptor autophosphorylation in insulin resistance: correlation with altered sensitivity to glucose transport and antilipolysis to insulin. J. Clin. Endocrinol. Metab. 66:992-999.

9. Thies, R. S., J. M. Molina, T. P. Ciaraldi, G. R. Freidenberg, and J. M. Olefsky. 1990. Insulin-receptor autophosphorylation and endogenous substrate phosphorylation in human adipocytes from control, obese, and NIDDM subjects. Diabetes. 39:250-259.

10. Freidenberg, G. R., D. Reichart, J. M. Olefsky, and R. R. Henry. 1988 Reversibility of defective adipocyte insulin receptor kinase activity in non-insulin-dependent diabetes mellitus: effect of weight loss. J. Clin. Invest. 82:13981406.

11. Nyomba, B. L., V. M. Ossowski, and C. Bogardus. 1989. Relationship between skeletal muscle insulin receptor tyrosine kinase activity and in vivo insulin action in man. Diabetes. 38(Suppl. 2):58A. (Abstr.)

12. National Diabetes Data Group. 1979. Classification and diagnosis of diabetes mellitus and other categories of glucose intolerance. Diabetes. 28:10391057.

13. Henry, R. R., P. Wallace, and J. M. Olefsky. 1986. Effects of weight loss on mechanisms of hyperglycemia in obese non-insulin-dependent diabetes mellitus. Diabetes. 35:990-998.

14. Bergstrom, J. 1962. Muscle electrolytes in man determined by neutron activation analysis on needle biopsy specimen: a study on normal subjects, kidney patients, and patients with chronic diarrhea. Scand. J. Clin. Lab. Invest. 14(Suppl. 68):1-110.

15. Revers, R. R., R. Henry, L. Schmeiser, O. Kolterman, R. Cohen, R. Bergenstal, K. Polonsky, J. Jaspan, A. Rubenstein, B. Frank, J. Galloway, and J. M. Olefsky. 1984. The effects of biosynthetic human proinsulin on carbohydrate metabolism. Diabetes. 33:762-770.

16. Steele, R. 1959. Influence of glucose loading and injected insulin on hepatic glucose output. Ann. NY Acad. Sci. 82:420-430.

17. Chiasson, J. L., J. E. Liljenqvist, W. W. Lacy, A. S. Jennings, and A. Cherrington. 1977. Gluconeogenesis: methodological approaches in vivo. Fed. Proc. 36:229-235.

18. Gray, R. S., J. A. Scarlett, J. Griffin, J. M. Olefsky, and O. G. Kolterman 1982. In vivo deactivation of peripheral, hepatic, and pancreatic insulin action in man. Diabetes. 31:929-936.

19. Desbuquois, B., and G. D. Aurbach. 1971. Use of polyethylene glycol to separate free and antibody-bound peptide hormones in radioimmunoassays. $J$. Clin. Endocrinol. Metab. 33:732-738.

20. Freidenberg, G. R., H. H. Klein, R. Cordera, and J. M. Olefsky. 1985. Insulin receptor kinase activity in rat liver: regulation by fasting and high carbohydrate feeding. J. Biol. Chem. 260:12444-12453.

21. Cuatrecasas, P. 1970. Protein purification by affinity chromatography: derivatization of agarose and polyacrylamide beads. J. Biol. Chem. 245:30593065 .
22. Olson, T. S., and M. D. Lane. 1987. Post-transitional acquisition of insulin binding capacity by the insulin receptor proreceptor: correlation to recognition by autoimmune antibody. J. Biol. Chem. 262:6816-6822.

23. Marshall, S., W. T. Garvey, and M. Geller. 1984. Primary culture of isolated adipocytes. A new model to study insulin receptor regulation and insulin action. J. Biol. Chem. 259:6376-6384.

24. Burant, C. R., M. K. Treutelaar, K. D. Allen, D. A. Sens, and M. G. Buse 1987. Comparison of insulin and insulin-like growth factor I receptors from rat skeletal muscle and L6 myocytes. Biochem. Biophys. Res. Commun. 147:100107.

25. Sowell, M. O., K. A. Robinson, and M. G. Buse. 1988. Phenylarsine oxide and denervation effects on hormone-stimulated glucose transport. Am. J. Physiol. 255:E159-E165.

26. Poggi, C., Y. LeMarchand-Brustel, J. Zapf, E. R. Froesch, and P. Freychet. 1979. Effects and binding of insulin-like growth factor $I$ in the isolated soleus muscle of lean and obese mice: comparison with insulin. Endocrinology. 105:723-730.

27. Freidenberg, G. R., M. Kladde, and J. M. Olefsky. 1986. Insulin activation of insulin receptor tyrosine kinase in intact rat adipocytes: an in vitro system to measure histone kinase activity of insulin receptors activated in vitro. $J$. Biol. Chem. 261:4691-4697.

28. Garvey, W. T., J. M. Olefsky, J. Griffin, R. F. Hamman, and O. G. Kolterman. 1985. The effect of insulin treatment on insulin secretion and insulin action in type II diabetes mellitus. Diabetes. 34:222-234.

29. Rizza, R. A., L. J. Mandarino, and J. E. Gerich. 1982. Cortisol-induced insulin resistance in man: impaired suppression of glucose production and stimulation of glucose utilization due to a postreceptor defect of insulin action. J. Clin. Endocrinol. Metab. 54:131-138.

30. DeFronzo, R. A., E. Jacot, E. Jequier, E. Maeder, J. Wahren, and J. P. Felber. 1981. The effect of insulin on the disposal of intravenous glucose: results from indirect calorimetry and hepatic and femoral venous catheterization. Diabetes. 30:1000-1007.

31. Bryer-Ash, M. 1989. Insulin-receptor kinase activity correlates with in vivo insulin action. Diabetes. 38:108-116.

32. Kono, T., and F. W. Barham. 1971. The relationship between the insulinbinding capacity of fat cells and the cellular response to insulin. J. Biol. Chem. 246:6210-6216.

33. Olefsky, J. M. 1976. Effects of fasting on insulin binding, glucose transport, and glucose oxidation in isolated rat adipocytes: relationships between insulin receptors and insulin action. J. Clin. Invest. 58:1450-1460.

34. Freidenberg, G. R., R. R. Henry, H. H. Klein, D. R. Reichart, and J. M. Olefsky. 1987. Decreased kinase activity of insulin receptors from adipocytes of non-insulin-dependent diabetic (NIDDM) subjects. J. Clin. Invest. 79:240-250.

35. Grigorescu, F., J. S. Flier, and C. R. Kahn. 1986. Characterization of binding and phosphorylation defects of erythrocyte insulin receptor in the Type $A$ syndrome of insulin resistance. Diabetes. 35:127-138.

36. Rubin, J. B., M. A. Shia, and P. F. Pilch. 1983. Stimulation of tyrosinespecific phosphorylation in vitro by insulin-like growth factor I. Nature (Lond.) 305:438-440.

37. Yu, K. T., M. A. Peters, and M. P. Czech. 1986. Similar control mechanisms regulate the insulin and type I insulin-like growth factor receptor kinases. Affinity-purified insulin-like growth factor I receptor kinase is activated by tyrosine phosphorylation of its beta subunit. J. Biol. Chem. 261:11341-11349. 